\title{
KUALITAS DAN PRODUKSI VERMIKOMPOS MENGGUNAKAN CACING AFRICAN NIGHT CRAWLER (Eudrilus eugeniae)
}

\section{Quality and Production of Vermicompost Using African Night Crawler Worms (Eudrilus eugeniae)}

\author{
Fahrizal Hazra*, Nabila Dianisa dan Rahayu Widyastuti \\ Departemen Ilmu Tanah dan Sumberdaya Lahan, Fakultas Pertanian, Institut Pertanian Bogor, Jl. Meranti \\ Kampus IPB Dramaga, Bogor 16680
}

\begin{abstract}
Adding organic fertilizer such as vermicompost can be done to overcome the deficiency problem of soil organic matter. One of the worm species which can be used in vermicomposting is Eudrilus eugeniae. Purpose of this research was to know how the combination of cow dung and rice straw impacts vermicompost quality from organic carbon, $N$, $P$, total $K$, urease enzyme activity and vermicompost production. Treatment that used in this research is randomized completely design with 4 treatments. The treatments are P1: feed $400 \mathrm{~g}$ of cow dung, P2: feed $400 \mathrm{~g}$ of rice straw, P3: feed 280 g of cow dung and $120 \mathrm{~g}$ of rice straw, and P4: feed $140 \mathrm{~g}$ of cow dung and $60 \mathrm{~g}$ of rice straw. The research result shows that real treatment impacts all parameters on the produced vermicompost. Production result is determined by ratio value of output/input (O/I). Quality and production of vermicompost on P4 is a treatment with the best result. It is because the combination of cow dung and rice straw gives a relatively complete macro nutrient result and the higher feed dose will gives higher vermicompost production.
\end{abstract}

Keyword: Cow dung, organic matter, rice straw, urease enzyme

ABSTRAK

Penambahan pupuk organik seperti vermikompos dapat dilakukan untuk mengatasi masalah kekurangan bahan organik tanah. Salah satu spesies cacing tanah yang biasa digunakan dalam vermicomposting adalah Eudrilus eugeniae. Penelitian ini bertujuan mengetahui pengaruh kombinasi antara kotoran sapi dan jerami padi terhadap kualitas vermikompos dari kandungan C-organik, N, P, K total dan aktivitas enzim urease serta produksi vermikompos yang dihasilkan. Penelitian ini menggunakan rancangan acak lengkap (RAL) dengan 4 perlakuan. Perlakuan berupa P1: pakan 400 g kotoran sapi, P2: pakan $400 \mathrm{~g}$ jerami padi, P3: pakan $280 \mathrm{~g}$ kotoran sapi dan $120 \mathrm{~g}$ jerami padi, dan P4: pakan $140 \mathrm{~g}$ kotoran sapi dan $60 \mathrm{~g}$ jerami padi. Hasil penelitian menunjukkan perlakuan secara nyata mempengaruhi semua parameter pada vermikompos yang dihasilkan. Hasil produksi ditentukan berdasarkan nilai nisbah output/input (O/I). Kualitas dan produksi vermikompos pada P4 merupakan perlakuan yang memiliki hasil terbaik. Hal ini dikarenakan pencampuran kombinasi kotoran sapi dan jerami padi memberikan hasil makro nutrisi yang relatif lengkap serta dosis pemberian pakan yang lebih tinggi akan memberikan hasil produksi vermikompos yang lebih tinggi.

Kata kunci: Kotoran sapi, bahan organik, jerami padi, enzim urease

\section{PENDAHULUAN}

Upaya peningkatan produksi budidaya tanaman yang sering dilakukan oleh petani di Indonesia yaitu dengan intensifikasi lahan. Intensifikasi lahan dapat mengakibatkan unsur hara terangkut melalui panen secara terus-menerus sehingga kandungan hara dalam tanah semakin rendah. Berdasarkan hal tersebut maka perlu dilakukan pemupukan yang berimbang. Namun demikian petani pada umumnya hanya memberikan pupuk kimia ke dalam tanah tanpa penambahan bahan organik. Hal ini dapat menyebabkan terjadinya kerusakan pada tanah, seperti rusaknya struktur tanah, pencucian hara berlebihan, dan rendahnya bahan organik (Savci, 2012). Salah satu upaya yang dapat dilakukan untuk mengatasi masalah kekurangan bahan organik adalah dengan menambahkan pupuk organik.

Vermikompos merupakan salah satu jenis pupuk organik yang dihasilkan dari proses pencernaan dalam tubuh cacing, yaitu berupa kotoran yang telah terfermentasi. Salah satu spesies cacing tanah yang biasa digunakan dalam vermicomposting adalah Eudrilus eugeniae (Banu et al., 2008). Cacing tanah jenis ini merupakan cacing tanah epigeik yang dianggap sebagai agen pengompos paling efisien di daerah tropis (Guerrerro et al., 1999) karena berkembang lebih cepat dan nafsu makannya yang lebih tinggi daripada cacing merah (Dominguez et al., 2000). Parmelee et al. (1990) menyatakan bahwa cacing tanah memakan bahan organik setara berat tubuh per hari. Dengan demikian, cacing ini dapat dimanfaatkan sebagai produsen vermikompos yang unggul. Selain jenis cacing, vermikompos yang dihasilkan juga dipengaruhi oleh jumlah dan bahan pakan yang diberikan. Besarnya jumlah limbah kotoran sapi dan jerami padi yang belum banyak dimanfaatkan menjadikan kedua limbah tersebut berpotensi sebagai pakan cacing. Kombinasi kotoran sapi dan jerami padi sebagai pakan cacing tanah dapat dijadikan pilihan alternatif sebagai 
teknologi pengolahan limbah. Oleh karena itu, pemberian komposisi pakan yang berbeda pada E. eugeniae diharapkan dapat memberikan pengaruh terhadap kualitas dan produksi vermikompos yang dihasilkan.

Penelitian ini bertujuan mengetahui pengaruh kombinasi antara kotoran sapi dan jerami padi terhadap kualitas vermikompos dari kandungan C-organik, N, P, K total dan aktivitas enzim urease serta produksi vermikompos.

\section{BAHAN DAN METODE}

Penelitian ini dilaksanakan pada bulan AprilAgustus 2018. Penelitian dilaksanakan di kebun percobaan Cikabayan IPB Dramaga, Laboratorium Kimia dan Kesuburan Tanah dan Laboratorium Bioteknologi Tanah, Departemen Ilmu Tanah dan Sumberdaya Lahan, Fakultas Pertanian, Institut Pertanian Bogor.

Alat yang digunakan dalam penelitian ini ialah shaker, oven, erlenmeyer $500 \mathrm{ml}$, gelas piala $100 \mathrm{ml}$, gelas ukur $25 \mathrm{ml}$, tabung reaksi, spektrofotometer, flamefotometer, software Microsoft Excel, Microsoft Word 2016 dan SAS 9.1.2. Bahan yang digunakan adalah tanah latosol, kotoran sapi, jerami padi, cacing $E$. eugeniae, $\mathrm{H}_{2} \mathrm{SO}_{4}, \mathrm{FeSO}_{4}, \mathrm{NaOH} 50 \%, \mathrm{KH}_{2} \mathrm{PO}_{4}$, pereaksi Nessler dan larutan standar ammonium $\left(100 \mu \mathrm{g} \mathrm{NH} \mathrm{NH}_{4}-\mathrm{N}\right.$ $\left.\mathrm{ml}^{-1}\right)$.

\section{Metode Penelitian}

\section{Persiapan Media Hidup, Cacing dan Pakan Cacing}

Media hidup cacing tanah yaitu tanah latosol dengan wadah berupa keranjang berukuran $45 \mathrm{~cm}$ x $33 \mathrm{~cm}$ x $16 \mathrm{~cm}$. Cacing yang digunakan ialah jenis E. eugeniae. Cacing diletakkan di atas media dan akan masuk dengan sendirinya apabila media hidup tersebut cocok untuk hidup cacing (Susetyarini, 2007). Ciri fisik E. Eugeniae yaitu tubuhnya berwarna merah kecoklatan memudar, panjang tubuh 90-185 mm dengan lebar 4-8 mm, berat optimal 5-6 g dan secara taksonomi masuk dalam klasifikasi (Blakemore, 2015):

$\begin{array}{ll}\text { Famili } & \text { : Eudrilidae } \\ \text { Genus } & \text { : Eudrilus } \\ \text { Spesies } & : \text { Eudrilus eugeniae }\end{array}$

Pakan yang digunakan yaitu kotoran sapi dan jerami padi yang dikeringanginkan selama 14 hari. Cacing tanah tidak mempunyai gigi sehingga pakan yang diberikan sebaiknya dalam bentuk bubur guna meningkatkan daya cerna cacing (Hermawan, 2014). Perlakuan pemberian pakan cacing dilakukan menggunakan rancangan acak lengkap (RAL) dengan 4 perlakuan dan 3 ulangan seperti yang disajikan pada Tabel 1.

Perbedaan frekuensi pemberian pakan disebabkan perbedaan laju cacing E. eugeniae dalam mengonsumsi bahan pakan dalam setiap perlakuan. Salah satu faktor yang mempengaruhi laju dekomposisi bahan organik yaitu ukuran bahan organik (Susanti dan Halwany, 2017). Ukuran bahan pakan yang lebih halus dengan jumlah yang lebih sedikit akan menyebabkan bahan pakan lebih cepat habis sehingga frekuensi pemberian pakan akan menjadi lebih tinggi dan dekomposisi berjalan lebih cepat.

\section{Pemeliharaan Media Hidup Cacing dan Pemanenan Vermikompos}

Pemeliharaan media cacing tanah dilakukan dengan menjaga kegemburan media melalui proses pengadukan. Selain pengadukan, dilakukan penyemprotan untuk menjaga suhu dan kelembaban media. Proses pemanenan dilakukan setelah membudidaya cacing selama sebulan dengan cara mengambil dan menimbang bobot vermikompos yang dihasilkan.

\section{Analisis Laboratorium}

Analisis kimia yang dilakukan adalah C-organik, $\mathrm{N}$, $\mathrm{P}$ dan $\mathrm{K}$ total dengan metode pengabuan basah. Senyawa yang digunakan sebagai pengekstrak adalah $\mathrm{H}_{2} \mathrm{SO}_{4}$. Ekstrak yang telah didapat kemudian diukur kandungan nitrogen dengan metode Kjeldahl, fosfor dengan spectrophotometry dan kalium dengan flamephotometry. Analisis biologi vermikompos berupa pengukuran aktivitas enzim urease yang dinyatakan sebagai unit/g vermikompos. Aktivitas enzim urease dihitung berdasarkan rumus (Schinner et al., 1996) di bawah:

Tabel 1. Komposisi tanah latosol, cacing Eudrilus eugeniae, bahan pakan berupa kotoran sapi dan jerami padi, frekuensi pemberian pakan dan total input tiap perlakuan

\begin{tabular}{ccccccc}
\hline \multirow{2}{*}{ Perlakuan } & $\begin{array}{c}\text { Tanah latosol } \\
(\mathrm{g})\end{array}$ & $\begin{array}{c}\text { Cacing E. Eugeniae } \\
(\mathrm{g})\end{array}$ & \multicolumn{2}{c}{ Bahan Pakan } & & Kotoran Sapi \\
& & & $\begin{array}{c}\text { Jerami Padi } \\
(\mathrm{g})\end{array}$ & Frekuensi* & $\begin{array}{c}\text { Total input } \\
(\mathrm{g})\end{array}$ \\
\hline P1 & & & 400 & 0 & & 7,600 \\
P2 & \multirow{2}{*}{200} & 0 & 400 & 4 & 5,600 \\
P3 & 4000 & & 280 & 60 & 11 & 6,200 \\
P4 & & & 280 & 120 & 9 & 7,600 \\
\hline
\end{tabular}

*) Berdasarkan perbedaan laju cacing dalam mengonsumsi bahan pakan dalam setiap perlakuan

Keterangan: P1= pakan berupa 400 g kotoran sapi; $\mathrm{P} 2=$ pakan berupa 400 g jerami padi; $\mathrm{P} 3=$ pakan berupa $140 \mathrm{~g}$ kotoran sapi dan $60 \mathrm{~g}$ jerami padi; dan $\mathrm{P} 4=$ pakan berupa $280 \mathrm{~g}$ kotoran sapi dan $120 \mathrm{~g}$ jerami padi.

$$
\text { Aktivitas urease }=\frac{(S-C) \cdot 10 \cdot A \cdot 100}{B \cdot \% d m \cdot a \cdot b}
$$

Keterangan :

$$
\begin{array}{llll}
\mathrm{S} & =\text { Konsentrasi sampel }\left(\mu \mathrm{g} \mathrm{NH}_{4}{ }^{+}\right) & \mathrm{B} & =\text { Bobot sampel pupuk }(\mathrm{g}) \\
\mathrm{C} & =\text { Konsentrasikontrol }\left(\mu \mathrm{g} \mathrm{NH}_{4}{ }^{+}\right) & \% \mathrm{dm} & =\text { Faktor bobot kering pupuk }
\end{array}
$$


$\begin{array}{ll}100 & =\text { Faktor pengenceran } \\ \mathrm{A} & =\text { Volume ekstrak }(\mathrm{ml})\end{array}$

\section{HASIL DAN PEMBAHASAN}

\section{Karakteristik Media dan Pakan}

\section{Bahan Tanah}

Analisis tanah dilakukan untuk menilai status hara dalam kaitannya terhadap tanah sebagai media hidup cacing. Tanah yang digunakan sebagai media hidup cacing dalam penelitian ini adalah Latosol Dramaga dengan hasil pengukuran seperti yang disajikan pada Tabel 2 .

Tabel 2. Karakteristik sifat kimia Latosol Dramaga

\begin{tabular}{lcrc}
\hline \multicolumn{1}{c}{ Parameter } & Metode* & \multicolumn{1}{c}{ Nilai } & Kriteria \\
\hline pH 1:5 & $\mathrm{H}_{2} \mathrm{O}$ & 4.80 & Masam \\
C-organik (\%) & Walkley and Black & 1.57 & Rendah \\
$\mathrm{N}$ total $(\%)$ & Kjeldahl & 0.23 & Sedang \\
$\mathrm{P}(\mathrm{ppm})$ & Bray I & 3.58 & Sangat Rendah \\
$\mathrm{Ca}\left(\mathrm{cmol}(+) \mathrm{kg}^{-1}\right)$ & $\mathrm{N} \mathrm{NH}_{4} \mathrm{OAc} \mathrm{pH} \mathrm{7.0}$ & 0.48 & Sangat Rendah \\
$\mathrm{Mg}\left(\mathrm{cmol}(+) \mathrm{kg}^{-1}\right)$ & $\mathrm{N} \mathrm{NH}_{4} \mathrm{OAc} \mathrm{pH} \mathrm{7.1}$ & 0.23 & Sangat Rendah \\
$\mathrm{K}\left(\mathrm{cmol}(+) \mathrm{kg}^{-1}\right)$ & $\mathrm{N} \mathrm{NH}_{4} \mathrm{OAc} \mathrm{pH} \mathrm{7.2}$ & 0.18 & Rendah \\
$\mathrm{Na}\left(\mathrm{cmol}(+) \mathrm{kg}^{-1}\right)$ & $\mathrm{N} \mathrm{NH}_{4} \mathrm{OAc} \mathrm{pH} \mathrm{7.3}$ & 0.08 & Sangat Rendah \\
$\mathrm{KTK}\left(\mathrm{cmol}(+) \mathrm{kg}^{-1}\right)$ & $\mathrm{N} \mathrm{NH}_{4} \mathrm{OAc} \mathrm{pH} 7.4$ & 16.18 & Rendah \\
$\mathrm{KB}(\%)$ & & 5.98 & Sangat Rendah \\
$\mathrm{Al}\left(\mathrm{cmol}(+) \mathrm{kg}^{-1}\right)$ & & 4.59 & \\
$\mathrm{H}\left(\mathrm{cmol}(+) \mathrm{kg}^{-1}\right)$ & $\mathrm{N} \mathrm{KCl}$ & 0.52 & \\
$\mathrm{Fe}(\mathrm{ppm})$ & & 23.41 & \\
$\mathrm{Cu}(\mathrm{ppm})$ & $\mathrm{DTPA}$ & 1.15 & \\
$\mathrm{Zn}(\mathrm{ppm})$ & & 1.93 & \\
$\mathrm{Mn}(\mathrm{ppm})$ & & 119.53 & \\
\hline
\end{tabular}

*handbook of soil analysis

\section{Bahan Pakan}

Karakteristik bahan pakan yang digunakan dapat mencerminkan kualitas pupuk organik yang akan dihasilkan. Kotoran sapi menghasilkan nilai yang lebih baik dibandingkan jerami padi pada semua parameter seperti yang disajikan pada Tabel 3. Hasil analisis kandungan kotoran sapi relevan dengan penelitian Lingaiah dan Rajasekaran (1986). Tingginya hara pada kotoran sapi dapat meningkatkan hara yang terkandung dalam bahan pakan dan meningkatkan proses dekomposisi karena jumlah mikroorganisme yang berada pada bahan pakan akan semakin banyak (Agus, 2014). Hasil analisis kandungan jerami padi relevan dengan penelitian yang telah dilakukan Gaur (1983). Menurut Ansari et al. (2014), pencampuran kotoran sapi dengan jerami padi dilakukan karena jerami padi merupakan sumber hara yang potensial dalam menambah unsur hara.

\section{Kualitas Vermikompos}

Kualitas vermikompos dipengaruhi oleh berbagai parameter, seperti C-organik, $\mathrm{N}$ total, Nisbah $\mathrm{C} / \mathrm{N}, \mathrm{P}$ dan $\mathrm{K}$ total serta aktivitas enzim urease. Berdasarkan hasil analisis sidik ragam menunjukkan bahwa perlakuan secara nyata mempengaruhi semua parameter pada vermikompos

$$
\begin{aligned}
& =\mathrm{BM} \mathrm{NH}_{4}^{+}(\mathrm{g} / \mathrm{mol}) \\
& =\text { Waktu inkubasi }
\end{aligned}
$$

yang dihasilkan selama sebulan seperti yang disajikan pada Tabel 4. Hasil pengukuran $\mathrm{pH}$ vermikompos pada semua perlakuan relevan terhadap Peraturan Menteri Pertanian No.70/Permentan/SR.40/10/2011 yang menyatakan bahwa kompos bahan organik dapat digunakan bila telah memenuhi standar $\mathrm{pH}$ antara 4-9.

Tabel 3. Hasil analisis $\mathrm{pH}, \mathrm{C}$-organik, $\mathrm{N}$ total, Nisbah $\mathrm{C} / \mathrm{N}, \mathrm{P}$ dan $\mathrm{K}$ total pada bahan pakan yang digunakan berupa kotoran sapi dan jerami padi

\begin{tabular}{lrr}
\hline \multirow{2}{*}{ Parameter } & \multicolumn{2}{c}{ Bahan Pakan } \\
\cline { 2 - 3 } & Kotoran Sapi & \multicolumn{1}{c}{ Jerami Padi } \\
\hline $\mathrm{pH} \mathrm{H}{ }_{2} \mathrm{O} 1: 5$ & 7.74 & 6.93 \\
C-organik $(\%)$ & 34.48 & 18.26 \\
$\mathrm{~N}$ total $(\%)$ & 1.05 & 0.45 \\
Nisbah C/N & 32.84 & 40.64 \\
P total $(\mathrm{ppm})$ & 84.62 & 18.01 \\
K total $(\mathrm{ppm})$ & $8,018.77$ & $6,600.89$ \\
\hline
\end{tabular}

Parameter lain yang disajikan pada Tabel 4 adalah nilai C-organik, N, P dan $\mathrm{K}$ total. Tingginya nilai $\mathrm{C}$ organik, $\mathrm{N}$ dan $\mathrm{K}$ total pada $\mathrm{P} 4$ membuktikan bahwa kombinasi kotoran sapi dan jerami padi sangat baik dalam hal meningkatkan kualitas kandungan hara vermikompos. Hal menarik lainnya yang ditemukan pada Tabel 4 adalah kandungan C-organik, N, P dan $\mathrm{K}$ total pada P1 dan P2 relevan terhadap input bahan pakan yang digunakan. Hal ini menyebabkan kandungannya pada P1 lebih tinggi dibandingkan P2. Hal tersebut dikarenakan bahwa unsur hara yang terkandung pada kotoran sapi cukup kaya karena jenis makanan hewan tersebut cukup memiliki sumber hara yang memadai. Untuk P3 dan P4, kandungan $\mathrm{N}, \mathrm{P}$ dan $\mathrm{K}$ total yang dihasilkan tidak berbeda nyata karena proporsi pakan yang diberikan pun sama, hanya jumlah yang diberikan yang berbeda, namun secara nilai $\mathrm{P} 4$ relatif lebih baik daripada P3. Hal ini dinyatakan dalam Subowo (2010), bahwa tingginya pemberian bahan organik di dalam tanah dengan dosis yang tinggi akan meningkatkan aktivitas organisme dan akan meningkatkan kandungan hara dalam tanah.

Vermicomposting meningkatkan kandungan $\mathrm{N}$ total dan menurunkan nisbah $\mathrm{C} / \mathrm{N}$ lebih cepat dari pada pengomposan tradisional (Lazcano et al., 2008). Nisbah $\mathrm{C} / \mathrm{N}$ yang tinggi menunjukkan bahwa kandungan unsur hara yang tersedia untuk tanaman jumlahnya sedikit sedangkan nisbah $\mathrm{C} / \mathrm{N}$ yang sedang menunjukkan ketersediaan unsur hara yang cukup untuk tanaman (Surtinah, 2013). Nisbah C/N pada P1, P2 dan P3 sudah memenuhi standar pupuk organik yang telah ditetapkan dalam Peraturan Menteri Pertanian No.70/Permentan/SR.140/10/2011. Nilai nisbah C/N pada P4 tidak berbeda nyata dengan P3 sehingga dapat dikatakan dari segi kualitas, seluruh vermikompos yang dihasilkan dalam penelitian ini memenuhi kriteria untuk diaplikasikan.

Tabel 4. Hasil analisis kadar pH, C-organik, $\mathrm{N}$ total, Nisbah $\mathrm{C} / \mathrm{N}, \mathrm{P}$ dan $\mathrm{K}$ total pada vermikompos yang dihasilkan

\begin{tabular}{ccrrrrr}
\hline Perlakuan & $\mathrm{pH}$ & C-org $(\%)$ & $\mathrm{N}(\%)$ & Nisbah C/N & $\mathrm{P}(\mathrm{ppm})$ & \multicolumn{1}{c}{$\mathrm{K}(\mathrm{ppm})$} \\
\hline $\mathrm{P} 1$ & $6.98 \mathrm{~b}$ & $16.74 \mathrm{bc}$ & $0.77 \mathrm{c}$ & $21.56 \mathrm{ab}$ & $3.28 \mathrm{~b}$ & $2,889.7 \mathrm{bc}$ \\
$\mathrm{P} 2$ & $5.82 \mathrm{~b}$ & $11.36 \mathrm{ab}$ & $0.56 \mathrm{~b}$ & $20.01 \mathrm{a}$ & $0.86 \mathrm{a}$ & $1,720.6 \mathrm{~b}$
\end{tabular}




\begin{tabular}{rrrrrrrr}
\hline & & & & & & & \\
$\mathrm{P} 3$ & $6.40 \mathrm{~b}$ & $17.63 \mathrm{c}$ & $0.73 \mathrm{bc}$ & $24.08 \mathrm{ab}$ & $0.7 \mathrm{a}$ & $2,436.7 \mathrm{bc}$ \\
& $\mathrm{P} 4$ & $7.03 \mathrm{~b}$ & $26.24 \mathrm{~d}$ & $0.88 \mathrm{c}$ & $29.93 \mathrm{~b}$ & $1.19 \mathrm{a}$ & $3,737.4 \mathrm{c}$ \\
\hline
\end{tabular}

Keterangan: $\mathrm{P} 1=$ pakan berupa $400 \mathrm{~g}$ kotoran sapi; $\mathrm{P} 2=$ pakan berupa $400 \mathrm{~g}$ jerami padi; $\mathrm{P} 3=$ pakan berupa $140 \mathrm{~g}$ kotoran sapi dan $60 \mathrm{~g}$ jerami padi; $\mathrm{P} 4=$ pakan berupa 280 g kotoran sapi dan $120 \mathrm{~g}$ jerami padi; Nilai dengan huruf yang berbeda pada kolom yang sama menunjukkan berbeda nyata menurut uji lanjut Duncan pada taraf 5\%.

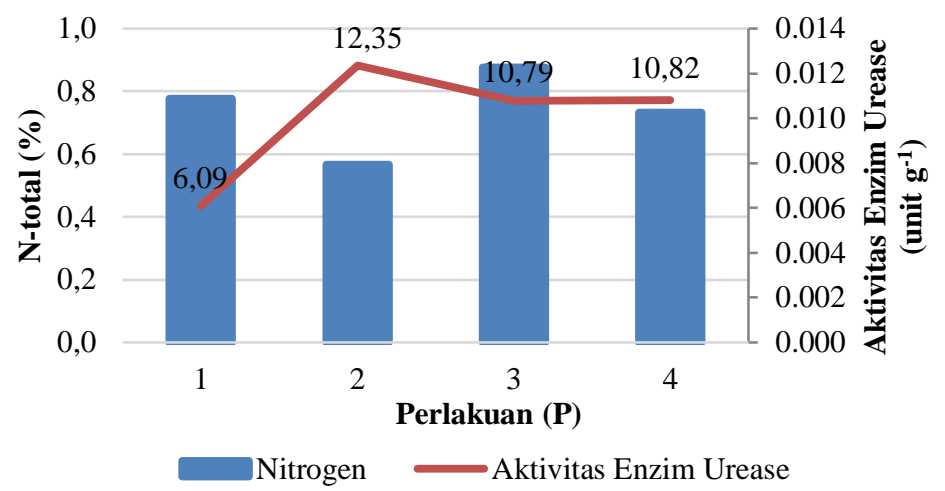

Gambar 1. Grafik hubungan antara $\mathrm{N}$ total terhadap aktivitas enzim urease

Keterangan: P1= pakan berupa $400 \mathrm{~g}$ kotoran sapi; $\mathrm{P} 2=$ pakan berupa $400 \mathrm{~g}$ jerami padi; $\mathrm{P} 3=$ pakan berupa $280 \mathrm{~g}$ kotoran sapi dan $120 \mathrm{~g}$ jerami padi; dan $\mathrm{P} 4=$ pakan berupa $140 \mathrm{~g}$ kotoran sapi dan $60 \mathrm{~g}$ jerami padi.

Saluran pencernaan cacing tanah mengandung berbagai konsorsium organisme sinergis seperti protozoa, bakteri dan mikro fungi yang mampu mendegradasi senyawa selulosa dan mengandung berbagai enzim seperti lipase, protease, urease, selulase, amilase dan kitinase (Pathma dan Saktivhel, 2012). Enzim urease adalah enzim yang berperan penting sebagai katalis hidrolisis urea menjadi amoniak dan asam karbamat (Banerjee dan Aggarwal, 2012). Aktivitas enzim urease tanah ditetapkan dengan mengukur produk dari hidrolisis urea oleh urease yaitu $\left[\mathrm{NH}^{+-} \mathrm{N}\right]$. Berdasarkan data pada Gambar 1, dapat terlihat bahwa aktivitas enzim urease terendah pada P1 dan tertinggi pada $\mathrm{P} 2$, dengan nilai yang tidak tidak berbeda nyata terhadap P3 dan P4. Nilai tersebut menjadi penting dalam kaitan pengaplikasian vermikompos tersebut ke tanah, sebab dalam Wang et al. (2012), terdapat pengaruh nyata antara aktivitas enzim urease terhadap unsur $\mathrm{N}$ yang terkandung di dalam tanah, dimana enzim urease menyediakan energi internal dan eksternal bagi organisme untuk menggunakan urea dan menghidrolisisnya menjadi amonia yang dapat digunakan oleh tanaman. Menurut Sirko (2000), enzim urease dapat digunakan sebagai indikator untuk memprediksi banyaknya kandungan $\mathrm{N}$ dalam bentuk belum tersedia dalam suatu lingkungan. Berdasarkan pernyataan tersebut, maka tingginya nilai aktivitas enzim urease pada P2 diindikasikan karena pada perlakuan tersebut masih banyak $\mathrm{N}$ yang belum tersedia.

\section{Produksi Vermikompos}

Perhitungan nisbah Output/Input (O/I) didasari oleh adanya perbedaan input yang diberikan ke dalam masing-masing perlakuan dan output yang dihasilkan. Output yang dihasilkan berupa kotoran cacing yang memiliki ciri-ciri berwarna kehitaman, struktur remah, tekstur halus dan tidak berbau (Trimulat, 2013). Nisbah $\mathrm{O} / \mathrm{I}$ terendah dimiliki oleh perlakuan kontrol dan tertinggi pada P4. Nilai tersebut menunjukkan efisiensi dari perlakuan terhadap jumlah vermikompos yang dihasilkan.
Hal menarik yang ditemukan pada Tabel 5 adalah P1 memiliki nilai yang nyata lebih tinggi dibandingkan P2. Hal ini disebabkan rendahnya nisbah $\mathrm{C} / \mathrm{N}$ pada bahan pakan P1 dibandingkan dengan bahan pakan P2. Nisbah $\mathrm{C} / \mathrm{N}$ bahan pakan sangat berkaitan terhadap tingkat konsumsi pakan cacing yang berujung pada dampak terhadap produksi yang dihasilkan.Perbedaan nilai P3 dan P4 disebabkan frekuensi pemberian pakan yang lebih tinggi pada P3 menyebabkan cacing stres sehingga menurunkan performa cacing dalam menghasilkan vermikompos. Perbedaan frekuensi pemberian pakan dikarenakan adanya perbedaan ukuran partikel bahan pakan. Menurut Yuliarti (2009), ukuran bahan pakan yang lebih halus dapat meningkatkan kemampuan makan cacing tanah, sedangkan bahan pakan yang berserat dapat menyebabkan cacing kesulitan dalam mengonsumsi pakan. Kandungan serat kasar yang cukup tinggi dalam bahan pakan sulit untuk didegradasi karena semakin banyak senyawa lignin membungkus komponen selulosa dan hemiselulosa. Salah satu penghasil enzim selulase adalah bakteri, yang disebut juga sebagai bakteri selulotik yang merupakan bakteri penghasil enzim selulase yang menghidrolisis selulosa menjadi bentuk yang lebih sederhana (Meryandini et al., 2009). Bakteri selulolitik dalam saluran pencernaan cacing tanah dapat mendegradasi selulosa. Hal ini akan bermanfaat untuk meningkatkan senyawa-senyawa yang diperlukan untuk pertumbuhan tanaman atau organisme lain (Reanida et al., 2012).

Tabel 5. Hasil perhitungan total input pakan, produksi vermikompos dan nisbah output/input (O/I) vermikompos yang dihasilkan

\begin{tabular}{crrr}
\hline Perlakuan & Input $(\mathrm{g})$ & Output $(\mathrm{g})$ & \multicolumn{1}{c}{ Nisbah O/I } \\
\hline P1 & 7,600 & 6,940 & $0.91 \mathrm{c}$ \\
P2 & 5,600 & 3,927 & $0.70 \mathrm{~b}$ \\
P3 & 6,200 & 4,441 & $0.72 \mathrm{~b}$ \\
P4 & 7,600 & 7,340 & $0.96 \mathrm{c}$ \\
\hline
\end{tabular}

Keterangan: $\mathrm{P} 1=$ pakan berupa 400 g kotoran sapi; $\mathrm{P} 2=$ pakan berupa $400 \mathrm{~g}$ jerami padi; $\mathrm{P} 3=$ pakan berupa $140 \mathrm{~g}$ kotoran sapi dan 60 g jerami padi; $\mathrm{P} 4=$ pakan berupa 280 g kotoran sapi dan 120 g jerami padi; Nilai dengan huruf yang berbeda pada kolom 
yang sama menunjukkan berbeda nyata menurut uji lanjut Duncan pada taraf $5 \%$.

\section{SIMPULAN}

Perlakuan dengan pakan kombinasi menghasilkan vermikompos yang lebih baik secara kualitas dan kuantitas dibandingkan dengan perlakuan pakan tunggal. Perlakuan P4 merupakan perlakuan terbaik dengan nilai parameter kualitas, yakni C-organik, $\mathrm{N}$ total, dan $\mathrm{K}$ total. Perlakuan P4 juga secara kuantitas menghasilkan produksi terbaik dengan nisbah $\mathrm{O} / \mathrm{I}$ tertinggi.

\section{DAFTAR PUSTAKA}

Agus, C., E. Faridah, D. Wulandari dan B.H. Purwanto. 2014. Peran mikroba starter dalam dekomposisi kotoran ternak dan perbaikan kualitas pupuk kandang. Jurnal Manusia dan Lingkungan, 21(2): 179-187.

Ansari, H., Jamilah dan Mukhlis. 2014. Pengaruh dosis pupuk dan jerami padi terhadap kandungan unsur hara tanah serta produksi padi sawah pada sistem tanam SRI (System of Rice Intensification). Jurnal Online Agroekoteknologi, 2(3):1048-1055.

Banerjee, S. and A. Aggarwal. 2012. Isolation, partial purification, characterization and inhibition of urease (EC 3.5.1.5) enzyme from the Cajanus cajan seeds. Asian Journal of Bio Science, 7(1):203-209.

Banu, J.R., I.T. Yeom, S. Esakkiraj, N. Kumar and S. Logakanthi. 2008. Biomanagement of sagosludge using an earthworm, Eudrilus eugeniae. J. Environ Bio., 9(1):453-468.

Blakemore, R.J. 2015. Eco taxonomic profile of an iconic vermicomposter the 'African Night Crawler' earthworm, Eudrilus eugeniae. African Invertebrates, 56(3): 527-548.

Dominguez, J., C.A. Edwards and M. Webster. 2000. Vermicomposting of sewage sludge: effect of bulking materials on the growth and reproduction of the earthworm Eisenia andrei. Pedobiologia, 44(1):24-32.

Gaur, A.C. 1983. A Manual Rural Composting FAO. The United Nation, Rome.

Guerrero, R.D., L.G. Villegas and L.A. Guerrero. 1999. Studies on the production and utilization of vermicompost produced with the African Night Crawler (Eudrilus eugeniae) in the Philippines. Philippine Technology Journal, 24(1):57-62.

Hermawan. 2014. Usaha Budidaya Cacing Tanah Lumbricus rubellus. Pustaka Baru, Yogyakarta.

Lazcano, C., M.G. Brandon and J. Dominguez. 2008. Comparison of the effectiveness of composting and vermicomposting for the biological stabilization of cattle manure. Chemosphere, 72: 1013-1019.
Lingaiah, V. and P. Rajasekaran P. 1986. Biodigestion of cowdung and organic wastes mixed with oil cake in relation to energy. Agricultural Wastes, 17: 161-173.

Meryandini, A., W. Wahyu, M. Besty, C.S. Titi, R. Nisa dan S. Hasrul. 2009. Isolasi bakteri selulolitik dan karakterisasi enzimnya. Makara Journal of Sains, 13(1):33-38.

Parmelee, R.W., M.H. Beare, W. Cheng, P.F. Hendrix, S.J. Rider, D.A. Crossley and D.C. Coleman. 1990. Earthworm and enchytraeids in conventional and no tillage agroecosystems: A biocide approach to asses their role in organic matter breakdown. Biology Fertility Soils, 10: 1-10.

Pathma, J. and N. Sakthivel. 2012. Microbial diversity of vermicompost bacteria that exhibit useful agricultural traits and waste management potential. Springerplus, 1(26): 1-19.

[Permentan] Peraturan Menteri Pertanian Nomor 70/Permentan/SR.140/10/2011. 2011. Pupuk Organik, Pupuk Hayati, dan Pembenah Tanah. Kementerian Pertanian.

Reanida, P., Supriyanto dan Salamun. 2012. Eksplorasi Bakteri Selulolitik Dari Tanah Mangrove Wonorejo Surabaya [Tesis]. Universitas Airlangga. Surabaya.

Savci, S. 2012. Investigation of effect of chemical fertilizers on environment. APCBEE Proceedia, 287-292.

Schinner, F., E. Kandeler and O.R. Margesin. 1996. Methods in Soil Boilogy. Spinger, German.

Sirko, A. and R. Brodzik. 2000. Plant ureases: roles and regulations. Acta Biochimica Polonica, 47(4):1189-1194.

Subowo, G. 2010. Strategi efisiensi penggunaan bahan organik untuk kesuburan dan produktivitas tanah melalui pemberdayaan sumberdaya hayati tanah. Jurnal Sumberdaya Lahan, 4(1):13-25.

Surtinah. 2013. Pengujian kandungan unsur hara dalam kompos yang berasal dari serasah tanaman jagung manis (Zea mays). Jurnal Ilmiah Pertanian, 11(1):16-26.

Susanti, P.D. dan W. Halwany. 2017. Dekomposisi serasah dan keanekaragaman makrofauna tanah pada Hutan Tanaman Industri Nyawai (Ficus variegate Blume). Jurnal Ilmu Kehutanan, 11(2):212-223.

Susetyarini, R.E. 2007. Jumlah dan berat cocoon cacing tanah (Lumbricus rubellus) yang diberi PMSG, pakan tambahan berupa kotoran domba dan kotoran sapi. Jurnal Protein, 14(1):1-8.

Trimulat. 2013. Membuat dan Memanfaatkan Kascing Pupuk Organik Berkualitas. PT Agromedia Pustaka. Jakarta.

Wang, B., X. Sha, B.L. Guo and H.Z. Guang. 2012. Changes in soil nutrient and enzyme activities 
under different vegetations in the loess plateau area, Northwest China. Catena, 92: 186-195.
Yuliarti, N. 2009. 1001 Cara Menghasilkan Pupuk Organik. Lily Publisher, Yogyakarta. 